\title{
Association of selected risk factors with bovine subclinical mastitis
}

\section{Associação de fatores de risco selecionados com mastite subclínica bovina}

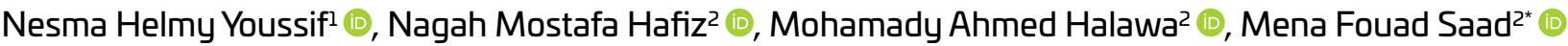

\begin{abstract}
A total of 695 Holstein Friesian lactating dairy cows were examined for the prevalence of subclinical mastitis (SCM) and its association with selected risk factors in a private dairy farm at Fayoum district, Egypt. 444 lactating cows with 1145 quarters were found positive for SCM with prevalence of $63.88 \%$ and $41.18 \%$ at cow and quarter level respectively based on California Mastitis Test (CMT), Electrical Conductivity (EC) that had a mean value of $6.27 \pm 0.066 \mathrm{mS} / \mathrm{cm}$ and Somatic Cell Count (SCC) with a mean value of $8.8 \times 10^{5} \pm 9.2 \times 10^{3}$ cells $/ \mathrm{ml}$. The risk factors investigated in this study revealed that the highest percentage of SCM was observed in winter, in cows at the late lactation stage with a percentage of 32.21 and 59.91 respectively. The results concluded that the young age cows were exposed to SCM more than old ones. While the occurrence of SCM was higher in cows with $2^{\text {nd }}, 3^{\text {rd }}$ and $1^{\text {st }}$ than those with $4,5,6^{\text {th }}$ parity number. The analytical results also revealed that there is a highly significant difference $(p<0.05)$ between numbers of parity. However, there is no significant difference $(p>0.05)$ between different stages of age, lactation and season as risk factors.
\end{abstract}

KEYWORDS: Subclinical mastitis, Risk factors, Age, Parity, Stage of lactation, Season

RESUMO: Um total de 695 vacas leiteiras Holstein Friesian lactantes foram examinadas para a prevalência de mastite subclínica (SCM) e sua associaçấo com fatores de risco selecionados em uma fazenda privada de leite no distrito de Fayoum, Egito. 444 vacas em lactação com 1145 quartos foram consideradas positivas para SCM com prevalência de 63.88\% e 41.18\% no nível de vacas e quartos, respectivamente com base no California Mastitis Test (CMT), Condutividade Elétrica (EC) que teve um valor médio de $6.27 \pm 0.066 \mathrm{mS} / \mathrm{cm}$ e Contagem de células somáticas (SCC) com um valor médio de $8.8 \times 10^{5} \pm 9.2$ $\times 10^{3}$ células $/ \mathrm{ml}$. Os fatores de risco investigados neste estudo revelaram que o maior percentual de SCM foi observado no inverno, em vacas no final da lactação com um percentual de 32.21 e 59.91 respectivamente. Os resultados concluíram que as vacas jovens foram mais expostas ao SCM do que as vacas velhas. Enquanto a ocorrência de SCM foi maior nas vacas com 2,3 e $1^{\text {a }}$ do que nas com 4, 5 e 6 números de paridade. Os resultados analíticos também revelaram que existe uma diferença altamente significativa $(\mathrm{p}<0.05)$ entre os números de paridade. No entanto, não há diferença significativa $(\mathrm{p}>0.05)$ entre os diferentes estágios de idade, lactação e estação do ano como fatores de risco.

PALAVRAS-CHAVE: Mastite subclínica, Fatores de risco, Idade, Paridade, Estágio de lactação, Estação

\section{INTRODUCTION}

Bovine mastitis is a global problem that negatively affects the animal health and quality \& quantity of milk. In addition, it causes huge financial losses to the dairy industry (AMENu; Shitu; Abera, 2016; Youssif et al., 2019).

Subclinical mastitis (SCM) is characterized by no obvious signs either within udder or milk. However, the milk production diminishes and the somatic cell count (SCC) elevates. SCM is characterized by changes in milk composition, milk
$\mathrm{pH}$ and ion concentration without any udder reaction marks (Baştan et al., 2015; Nesma et al., 2020).

The inflammatory process is usually initiated when bacteria enter the mammary gland through the teat canal and multiply in the milk. Therefore, leukocytes are released into the mammary gland in response to the bacterial invasion. The few amount of the somatic cells that are normally present in cow's milk attempt to overcome the infection immediately. Both bacteria and leukocytes in the infected parts 
of the udder liberate chemo-attractive products like prostaglandins, histamine, serotonin, Tumor Necrosis Factor and interferon that may be directly involved in the pathogenesis of the disease through the teat canal (SAMAD, 2008; Gonsalves et al., 2016).

The ordinary symptoms of inflammation comprise the dilation of blood vessels, the increased of permeability, edema, high blood flow, neutrophil migration, mammary activity reduction, pain and fever. Cow's mastitis is a multifocal condition and its manifestation based on many variables that may be related to the animal, environment or to the pathogen. The realization of risk factors is conclusive for the oversight schema for mastitis in dairy cows (QAYYUM et al., 2016).

'Risk Factor' is mentioned as any characteristics that elevates the probability of a disease occurrence. Risk factors such as breed, age, parity, herd size, stage of lactation, hygiene and weather have a great attention on cows subclinical mastitis (FRANDSON et al., 2009). BIFFA; DEBELA; BEYENE (2005); ALGAMMAL et al. (2020) mentioned that the subclinical mastitis is the main cause of cows mastitis in different countries in the world and Egypt. This investigation was achieved to study the association of selected factors of risk with the prevalence of subclinical mastitis in a dairy farm.

\section{MATERIALS AND METHODS}

\section{Study area}

This study was carried out to investigate the prevalence and associated risk factors for bovine subclinical mastitis. The harvest period took place from December 2016 to November 2017 in dairy herds located in Fayoum district, Egypt. The study duration was sectioned into the 4 year seasons.

\section{Dairy animals}

Six hundred and ninety five lactating cows (2780 quarters) from 2300 dairy cows herd were examined for the prevalence of SCM. The farm uses milking machine supported by Afimilk system, which is a milk meter that measures milk yield and milk Electrical Conductivity (EC) during milking to monitor cow health and milk production. The milking machine can detect the SCM automatically and gives warning alarm when the daily milk yield decreases and electrical conductivity increases than normal level.

\section{Description of the dairy farm and some constant risk factors}

The data was collected with the help of the farm manager concerning the farm, surroundings environment and the lactating cows. The data includes the following: Cow breed: Holstein Friesian; land type: cement; age average: $2-12$ years; weight average: $550-700 \mathrm{~kg}$; automatically milking; water source: municipal and running water supply in the milk parlor; pest control: exist and the cows were sprayed (once/week); insemination artificially; not applied oxytocin; a common water trough was available. The farms' cows were automatically milked three times daily and the milk was collected in big milk containers.

\section{Aseptic milk samples collection}

1145 quarter milk samples from 444 apparently healthy cows which were suspected to harbor SCM during milking by Afimilk system and did not show any visible abnormalities or any sign of clinical mastitis were collected according to Radostits et al. (2007) and were examined as follows:

A-California Mastitis Test (CMT) based on Schalm; Carroll; Jain (1971); Anri (2012): Lactating cows were tested using Schalm reagent (Sigma-Aldrich, 23608888) to detect SCM in four quarters of the udder.

B-Electrical Conductivity (EC) according to LinzelL; Peaker (1971): Electrical Conductivity was measured using Waterproof EC/TDS Tester (AD31\& AD 32), on a scale up to $200 \mathrm{mS} / \mathrm{cm}$ (milliSiemens per centimeter). The meter was calibrated with a specific standard solution before measuring the EC of milk samples. The meter electrode was washed with Distilled Water and dried with paper towels after each measurement.

C-Somatic cell counts (SCC) according to GonZalo et al. (2006): The Somatic Cell Counts were estimated using Bentley soma count 150 (115 Volts/ 60Hz/ 2Amps) (Chaska, MN 55318 , United States). The device measured the total number of milk SCC per $\mathrm{ml}$ of milk samples (MSCC/ml). The analysis of variance (ANOVA) test was conducted to test the possible significance $(P \leq 0.05)$ among different mean values using SPSS, version 25 . Typical EC of IMI to be $\geq 5.5 \mathrm{mS} / \mathrm{cm}$, cow with CMT score $\geq+1$ for at least one quarter was identified as a subclinical mastitis cow. A milk SCC concentration exceeding 200,000 cells / ml generally indicates that cows have an underlying IMI (KASIKCI et al., 2012; PANCHAL et al., 2016; VIKOVA et al., 2017).

\section{RESULTS AND DISCUSSION}

The data presented in (Table 1) reveals that the total number of animals inside the farm was 2300 dairy cows, including seven hundred and fifty (32.61\%) from them were classified as a dry group, 855 (37.17\%) were heifer and before weaning, and the lactating group was 695 cows with a percentage of 30.22 .

Table 1. Grouping of animals inside the examined farm $(n=2300)$.

\begin{tabular}{l|c|c}
\hline Group & No. & $\%$ \\
\hline Dry group & 750 & 32.61 \\
\hline Lactating group & 695 & 30.22 \\
\hline Heifer and before weaning & 855 & 37.17 \\
\hline
\end{tabular}

No. $=$ Number of dairy cows 
In this study, subclinical mastitis was found to affect 444 dairy cows out of a total of 695 dairy cows with 1145 affected quarters based on CMT, EC and SCC investigation (Table 2).

The results illustrated in (Table 3 ) showed that the highest prevalence of SCM was recorded in CMT score $(+1)$ at a percentage of 60.00 and the lowest prevalence was reported in CMT score $(+3)$ at a percentage of 8.00 .

The mean values of the SCC and EC in this study for the examined SCM quarter milk samples were $8.8 \times 10^{5} \pm 9.2 \times 10^{3}$ cell $/ \mathrm{ml}$ and $6.27 \pm 0.066 \mathrm{mS} / \mathrm{cm}$ respectively (Table 4).

Inspection of the data presented in (Table 5) revealed that there is a significant difference between both seasons: winter and autumn $(P<0.05)$ based on CMT, EC, and SCC test

Table 2. SCM quarters and SCM cows' percentages in the examined farm based on CMT, EC and SCC results.

\begin{tabular}{l|c|c} 
Positive samples & Number & $\%$ \\
\hline SCM quarters & $1145 / 2780$ & 41.18 \\
\hline SCM cows & $444 / 695$ & 63.88 \\
\hline
\end{tabular}

Table 3. Total number of SCM quarters in the farm based on CMT score $(n=1145)$.

\begin{tabular}{c|c|c} 
CMT score & No. of the affected quarters & $\%$ \\
+1 & 687 & 60.00 \\
\hline+2 & 367 & 32.00 \\
\hline+3 & 91 & 8.00 \\
\hline
\end{tabular}

Table 4. Statistical analytical results of SCC (cell/ml) and EC (mS/ $\mathrm{cm}$ ) of the examined SCM milk samples.

\begin{tabular}{l|c|c|c|c} 
Parameter & No. & Min & Max & Mean \pm SE \\
\hline SCC & 1145 & $2.5 \times 10^{5}$ & $2.7 \times 10^{6}$ & $8.8 \times 10^{5} \pm 9.2 \times 10^{3}$ \\
\hline EC & 1145 & 5.50 & 10.83 & $6.27 \pm 0.066$ \\
\hline
\end{tabular}

Max = Maximum Min = Minimum No. = number of positive SCM quarters

Table 5. Significant differences between seasons based on each SCM diagnostic test result.

\begin{tabular}{l|c|c|c} 
Diagnostic test & \multicolumn{2}{|c|}{ Seasons } & Sig. difference \\
CMT & & Spring & 0.108 \\
& Winter & Summer & 0.921 \\
& & Autumn & 0.011 * \\
\hline \multirow{3}{*}{ EC } & \multirow{3}{*}{ Winter } & Spring & 0.190 \\
& & Summer & 0.534 \\
& & Autumn & 0.001 * \\
\hline \multirow{3}{*}{ SCC } & \multirow{2}{*}{ Winter } & Spring & 0.204 \\
& & Summer & 0.896 \\
& & Autumn & $0.003^{*}$ \\
\hline
\end{tabular}

* Significant difference, $P$-value $<0.05$. results, but there were no significant differences of the same variables between other seasons.

The highest percentage of SCM (Table 6) was observed in $4-5$ years cows with a percentage of 48.42 , while winter was the season of the highest percentage (32.21\%) of the SCM inside the farm. On the other hand, the cows with $2^{\text {nd }}$, $3^{\text {rd }}$ parity number and cows at the late stage of lactation were exposed to SCM more than other cows.

The data presented in (Table 7) illustrated the significant difference between seasons in each risk factor based on SCM cows. The results revealed that there is a significant difference $(P<0.05)$ between winter and summer on one hand and autumn and summer on the other in parity and age as risk factors. However, there is no significant difference $(P>0.05)$ in the stage of lactation between the seasons.

Subclinical mastitis is related to changeable origin, seriousness and consequence depending on various agents. Reliable diagnostic methods are needed to detect subclinical mastitis such as California Mastitis Test, SCC and EC.

Table 6. Prevalence of subclinical mastitis based on various risk factors and significance differences between each risk factor stage.

\begin{tabular}{l|c|c|c}
$\begin{array}{l}\text { Various stages of } \\
\text { risk factors }\end{array}$ & $\begin{array}{c}\text { number of } \\
\text { positive SCM } \\
\text { cows }(n=444)\end{array}$ & $\%$ & $\begin{array}{c}\text { Sig. } \\
\text { difference }\end{array}$
\end{tabular}

Age

\begin{tabular}{|c|c|c|c|}
\hline 2-3 years & 117 & 26.35 & \multirow{5}{*}{$P>0.05$} \\
\hline $4-5$ years & 215 & 48.42 & \\
\hline 6-7 years & 67 & 15.09 & \\
\hline 8-9 years & 41 & 9.23 & \\
\hline$\geq 10$ years & 4 & 0.91 & \\
\hline \multicolumn{4}{|l|}{ Season } \\
\hline Winter & 143 & 32.21 & \multirow{4}{*}{$P>0.05$} \\
\hline Spring & 65 & 14.64 & \\
\hline Summer & 139 & 31.31 & \\
\hline Autumn & 97 & 21.84 & \\
\hline
\end{tabular}

Parity

\begin{tabular}{|c|c|c|c|}
\hline lst & 65 & 14.64 & \multirow{6}{*}{$P<0.05^{\prime}$} \\
\hline $2^{\text {nd }}$ & 167 & 37.61 & \\
\hline 3rd & 99 & 22.30 & \\
\hline 4th & 53 & 11.94 & \\
\hline $5^{\text {th }}$ & 34 & 7.66 & \\
\hline$\geq 6^{\text {th }}$ & 26 & 5.85 & \\
\hline \multicolumn{4}{|l|}{ Stage of lactation } \\
\hline Early (0-100 days) & 75 & 16.89 & \multirow{3}{*}{$P>0.05$} \\
\hline Mid (100-190 days) & 103 & 23.20 & \\
\hline Late (>190 days) & 266 & 59.91 & \\
\hline
\end{tabular}

Significant difference, $P$-value $<0.05$. 
Table 7. Significant differences between seasons in each risk factor based on subclinical mastitis cows.

\begin{tabular}{l|c|c|c} 
Risk factor & \multicolumn{2}{|c|}{ Seasons } & Sig. difference \\
Parity & & Winter & $0.013^{*}$ \\
& \multirow{3}{*}{ Summer } & Spring & 0.187 \\
& & Autumn & $0.004^{*}$ \\
\hline \multirow{3}{*}{ Age } & & Winter & $0.049 *$ \\
& \multirow{3}{*}{ Summer } & Spring & 0.298 \\
& & Autumn & 0.039 * \\
\hline \multirow{3}{*}{ Stage of lactation } & \multirow{3}{*}{ Summer } & Winter & 0.854 \\
& & Spring & 0.826 \\
& & Autumn & 0.824 \\
\hline
\end{tabular}

* Significant difference, $P$-value $<0.05$.

Therefore, any indicative test faults will happen when relying on a single test (JAEGER et al., 2017).

The total number of positive SCM quarters, depending on the three tests of CMT, SCC and EC were 1145 from 2780 examined quarters at a percentage of 41.18 . The results of this work are nearly similar to those reported by DASOHARI et al. (2017) - India; SARBA; Tola (2017)- Ethiopia; TrajChev et al. (2017) - Macedonia; Suleiman; Karimuribo; Mdegela (2018)- Tanzania. Lower data were registered by Mir; BANSAL; Gupta (2014) - India; Fadlelmoula et al. (2007) - Germany; Mendoza; Vera; Peña (2017) - Colombia, but the higher incidence was reported by SHAWKY et al. (2013) - Egypt; Östensson et al. (2013) - Vitnam; Bentr; Yohannes; Tolosa (2014) - Ethiopia.

This study shows that out of 695 examined lactating cows, 444 lactating cows were subclinical mastitic and the prevalence rate of SCM at cow level was $63.88 \%$. The result was consistent with Dasohari et al. (2017); Mekonnen et al. (2017) - Ethiopia; Mpatswenumugabo et al. (2017) - Rwanda; Suleiman; Karimuribo; Mdegela (2018). The comparatively lower results were reported by BAŞTAN et al. (2015) - Turkey; Iraguha; Hamudikuwanda; Mushonga (201 5) - Rwanda; Krieger et al. (2017) - Europe, while the higher incidences were reported by LANGER et al. (2014) India; Fadlelmoula et al. (2007); Prabhu et al. (2015) - India.

California Mastitis Test is a simple, inexpensive, rapid and highly sensitive test that accurately predicts the inflammatory cell counts in milk from quarters or pooled milk samples (Madut; Gadir; El JaliI, 2009). It is called Fast Mastitis Test (FMT), and is considered as indirect test that grossly measures the amount of (DNA), which is primarily a function of the number of nucleated (WBCs) in the milk. RAHMAn et al. (2010); SuriYASATHAPORN (2011); KaşıKçI et al. (2012) reported that a cow with CMT score $\geq+1$ for at least one quarter was identified as a SCM.

Chemotactic agents are released from leukocytes that are normally present in the milk or from damaged tissues that attract PMN into the lumen of the alveolus in large numbers, especially neutrophils, which increase the MSCC. The results demonstrated that the mean value of SCC of the subclinical mastitic quarter milk samples was $8.8 \times 10^{5} \pm 9.2 \times 10^{3} \mathrm{cell} / \mathrm{ml}$. Milk Somatic Cell Count is considered a universal standard method for diagnosis of the subclinical mastitis and the milk from SCM cows has SCC greater than $2 \times 10^{5} \mathrm{cell} / \mathrm{ml}$ (FERNANDES; OLIVEIRA; TAVOLARO, 2004; ANDREATTA et al., 2009; Youssif et al., 2020).

The EC measurement in milk is one of the screening tests for mastitis that has been widely evaluated. It evaluates the ability of a solution to conduct an electric current between 2 electrodes and is given in milli-Siemens per centimeter $(\mathrm{mS} / \mathrm{cm})$. EC increase is proportional to SCC increases (BIGGADIKE et al., 2002; Norberg et al., 2004). Typical EC of normal milk appears to be between 4.0 and $5.5 \mathrm{mS} / \mathrm{cm}$ at $25^{\circ} \mathrm{C}$ (DA Costa Ribeiro et al., 2016).

The presented results showed that; the minimum value of the EC of the examined SCM milk samples was $5.50 \mathrm{mS} / \mathrm{cm}$ and the maximum value was $10.83 \mathrm{mS} / \mathrm{cm}$ with a mean value of $6.27 \pm 0.066 \mathrm{mS} / \mathrm{cm}$. These results are consistent with Yoshida (2005).

This change in EC may be due to altered concentration of $\mathrm{Na}^{+}, \mathrm{K}^{+}$and $\mathrm{Cl}^{-}$in the $\mathrm{SCM}$ milk which causes the increase in EC. The EC of milk may be changed due to interaction of factors other than subclinical mastitis, such as environmental state, temperature, season, animal breed and stages of lactation. Therefore, a combination of above parameters would give more precise information on SCM as compared to a single parameter. The detection of the SCM at different stages would improve significantly (Panchal; SaWhney; Dang, 2016).

Based on SCM diagnostic test results; the $P$ value $(<0.05)$ between winter and autumn, might be due to the variation in the period and location of the study, animals number, parity number, lactation stage, and administration practices (Getaneh; Gebremedhin, 2017). This also indicates the ability of used SCM diagnostic tests to clear this statistical significant difference.

Our study exhibited that the highest prevalence of SCM was observed in 143 lactating cows in winter than in other seasons at $32.21 \%$, followed by summer, autumn and spring at percentage of 31.31, 21.84 and 14.64 respectively. There was not any significance $(p>0.05)$ statistical difference between the winter and other seasons. The findings were in line with the data recorded by Ellis et al. (2006); Rahman et al. (2009); Tiwari et al. (2013); LitwiŃCZUK; KRóL; BrodZiaK (2015). The higher subclinical mastitis prevalence may be due to bad environmental conditions which increased risk of SCM resulted from dirty teats and udders, as a result of moisture, mud especially in rains time and manure in the cow surrounding, considered as sources of environmental bacteria in milk. However; contrasting results were recorded by Wani; Bhatt (2003). Sudhan; Sharma (2010) concluded 
that the high temperature and relative humidity encourage the propagation of different bacteria, and the exhibition of animals to rising temperature can elevate the stress of the animal (reduced its immunity).

Moreover, the results exhibit that the highest percentage of SCM (59.91\%) was observed in the late stage of lactation (266 cows), followed by mid stage and early stage of lactation with a percentage of 23.20 and 16.89 respectively, but there was not any significance $(p>0.05)$ statistical differences between each stage of lactation. These results are in accordance with those reported by Syridion et al. (2013); Tancin (2013); Getaneh; Gebremedhin (2017); Patel; TRIVEDI (2018). The late lactation especially before drying is considered a critical period for udder health and the farmers should take more care of cows during this period. The explanation of the high prevalence of SCM at this stage may be due to the repeated and cumulative exposure to infection with contagious pathogens during milking practice or due to the removal of teats "plug" (Dingwell et al., 2004; Hussain et al., 2012), or due to increasing to the SCC that is linked with the defense improved of the mammary gland at calving time. Hence the importance of microbiological analyzes are important to clarify the cause of MSCC elevation.

During the stages of early and late lactation; the amount of the neutrophils is liable to increase, while the percentage of lymphocytes tends to reduce. A parturition period, the SCC is usually higher than 1 million cell/ $\mathrm{ml}$ and begins to decrease until it reaches up to $10^{5} \mathrm{cell} / \mathrm{ml}$ within 7-10 days post-partum. The high SCC has also been showed in the colostrum due to the excessive desquamation of epithelial cells in the milk (Sharma; Singh; Bhadwal, 2011).

The data recorded in our study revealed that the young cows were exposed to SCM more than old age ones, the cows of $4-5$ years had the highest percentage, followed by $2-3$ years, 6-7 years, $8-9$ years and $\geq 10$ years, with a percentage of 48.42 , $26.35,15.09,9.23$ and 0.91 respectively. This result may be attributed to high stress of nutrition, elevated milk production and maximum immunity level not occurring (SHELKE et al., 2019). Moreover, Oliver et al. (2005); Hussain et al. (2012); KLine; FLORES; JoYCe (20I8) reported that the older cows did not display more bacteria in their milk, or more somatic cells that fight off those bacteria and that they have a lower chance of contracting an Intra-mammary infection than low age animals.
Moreover, the results presented in this study showed that the occurrence of mastitis was higher in cows with $2^{\text {nd }}, 3^{\text {rd }}$ and $1^{\text {st }}$ parity number than those with $4,5,6^{\text {th }}$ parity number at a percentage of 37.61, 22.30, 14.64, 11.94, 7.66 and 5.85 respectively. This result may be due to possible lower resistance of first parity cows (mammary system not exposed earlier to the environmental pathogens). The mammary gland of primiparous cows is characterized by a smaller cisternal portion compared to pluriparous ones. Hence, it is useful to perform efficient mammary gland stimulation before teat cup attachment in order to induce a proper oxytocin release and excellent milk let down (Patel; Trivedi, 2018). The data reported by Zucali et al. (2009); Elbably; Emeash; AsmaA (2013) was consistent with these results.

These findings revealed that there is a significant difference $(p<0.05)$ between numbers of parity. This result is in agreement with those reported by QUADERI et al. (2013); Biressaw; Deme (2015); Prabhu (2015); Mureithi ; NJuguna (2016); Singh et al. (2017); Zeryehun ; Abera (2017); Seyoum et al. (2018). However, there are no significance differences $(p>0.05)$ between different stages of age, lactation and season. This result was supported by results mentioned by Bitew; Tafere; Tolosa (2010); AHMED; Abdelhamid; MoHAmmed (2015).

Based on parity and age as risk factors, there is a significant difference $(P<0.05)$ between summer and winter; summer and autumn. This may be due to the variation in parity number and age of the examined dairy cows. Moreover, the occurrence of SCM varies from season to another; because the growth and multiplication of organisms depend on some factors, like temperature and humidity (SUdHAN; SHARMA, 2010). Thus, the season is influences the appearance of SCM (Shathele, 2009). Training scheme of dairy farm workers and perfection of (HACCP) program are requested for safe milk production (Hafiz et al., 2016; Ibrahim; SaAd; Hafiz, 2020; Ibrahim; SaAd; Hafiz, 2021).

\section{CONCLUSIONS}

The occurrence of subclinical mastitis in a dairy farm varies depending on complex interaction among age, season, parity, and lactation stage. Therefore, it is recommended to give more attention to young age, primiparous cows', particularly in winter and late stage of lactation.

\section{REFERENCES}

AHMED, A. G.; ELFADIL, A. A.; ALDEEN, M. T. Study on bovine mastitis in small holder dairy cows in Northern State of Sudan. International Journal of Veterinary Science, v.4, n.2, p.81-86, 2015. www.ijvets.com
ALGAMMAL, A.M. et al. Prevalence, antimicrobial resistance profiles, virulence and enterotoxins-determinant genes of MRSA isolated from subclinical bovine mastitis in Egypt. Pathogens. v.9, ก. 5, p. 362, 2020. 
AMENU, K.; SHITU, D.; ABERA, M. Microbial contamination of water intended for milk container washing in smallholder dairy farming and milk retailing houses in southern Ethiopia. SpringerPlus, v.5, n.l, p.1195, 2016.

ANDREATTA, E. et al. Quality of minas frescal cheese prepared from milk with different somatic cell counts. Pesquisa Agropecuária Brasileira, v.44, n.3, p. 320-326, 2009.

ANRI, A. Manual for Mastitis Control in Developing Countries. Japan Livestock Technology Association, p. 37-56, 2012.

BAȘTAN, A. et al. The prediction of the prevalence and risk factors for subclinical heifermastitis in Turkish dairy farms. Turkish Journal of Veterinary and Animal Sciences, v.39, n.6, p. 682-687, 2015.

BENTI, A.D.; YOHANNES, A.; TOLOSA, T. Prevalence of clinical and sub-clinical mastitis on cross bred dairy cows at Holleta Agricultural Research Center, Central Ethiopia. Journal of Veterinary Medicine and Animal Health, v.6, n.l, p.13-17, 2014.

BIGGADIKE, H. J. et al. Evaluation of measurements of the conductivity of quarter milk samples for the early diagnosis of mastitis. Veterinary Record, v.150, n.21, p. 655-658, 2002.

BIFFA, D.; DEBELA, E.; BEYENE, F. Prevalence and risk factors of mastitis in lactating dairy cows in Southern Ethiopia. Int. J. Appl. Res. Vet. Med. v.3, n.3, p.189-198, 2005.

BIRESSAW, S.; Deme, T. Prevalence of bovine mastitis and determinant of risk factors in lemu Bilbilo District, Arsi Zone. Global Science Research Journals, v.3, n.2, p. 080-085, 2015.

BITEW, M.; TAFERE, A.; TOLOSA, T. Study on bovine mastitis in dairy farms of Bahir Dar and its environs. Journal of Animal and Veterinary Advances, v.9, n.23, p. 2912-2917, 2010.

DA COSTA RIBEIRO, A. B. et al. Evaluation of an electrical conductivity portable device as an alternative for subclinical mastitis detection. Revista de Salud Animal. v. 38, n.2, p. 131-135, 2016.

DASOHARI, A. et al. Epidemiological studies of subclinical mastitis in cows in and around Hyderabad. The Pharma Innovation, v.6, n.7, Part.G, p. 975, 2017.

DINCWELL, R. T. et al. Association of cow and quarter-level factors at drying-off with new intramammary infections during the dry period. Preventive Veterinary Medicine. v.63, p. 75-89, 2004.

ELBABLY, M.A.; EMEASH, H.H.; ASMAA, N.M. Risk factors associated with mastitis occurrence in dairy herds in Benisuef, Egypt. World's Veterinary Journal, v. 3, n.l, p. 5-10, 2013.

ELLIS, K. A. et al. The effect of farming system on dairy cow cleanliness in the UK and implications to udder health. Aspects of Applied Biology, v.79, p. 243-245, 2006.

FADLELMOULA, A. A. et al. The Effect of Management Factors on Somatic cell Counts and Specific Mastitis Causing Pathogens in Large Scale Dairy Units. Research Journal of Animal and Veterinary Sciences, v.2, p. 24-27, 2007.

FERNANDES, A. M.; OLIVEIRA, C. D.; TAVOLARO, P. Relationship between somatic cell count and composition of milk from individual holstein cows. Arquivos do Instituto Biológico, v.71, p. 163-166, 2004.
FRANDSON, R. D. et al. Anatomy and physiology of farm animals, 7th edition, Wiley Blavkwell, Ames, lowa, 2009.

GETANEH, A. M.; GEBREMEDHIN, E. Z. Meta-analysis of the prevalence of mastitis and associated risk factors in dairy cattle in Ethiopia. Tropical Animal Health and Production, v. 49, n. 4, p. 697-705, 2017.

GONSALVES, J. et al. Effect on bovine subclinical mastitis on milk yield and composition at the mammary quarter level. In National Mastitis Council, 2016.

GONZALO, C. et al. Evaluation of the overall accuracy of the DeLaval cell counter for somatic cell counts in ovine milk. Journal of Dairy Science, v.89, n.12, p. 4613-4619, 2006.

HAFIZ, N. M. et al. Detection of Mycobacterium avium subsp. paratuberculosis in raw buffaloe's milk. International Journal of ChemTech Research, v. 9, n.8, p. 123- 128, 2016.

HUSSAIN, R. et al. Possible risk factors associated with mastitis in indigenous cattle in Punjab, Pakistan. Pakistan Veterinary Journal, v.32, n.4, p. 605-608, 2012.

IBRAHIM, A.S.; SAAD, M.F.; NAGAH, M.HAFIZ. Toxic elements in dried milk and evaluation of their dietary intake in infant formula. International Journal of Veterinary Science, v. 9, n.4, p. 563-567. Doi: 10.37422/IJVS/20.070, 2020.

IBRAHIM, A.S.; SAAD, M.F.; NAGAH, M.HAFIZ. Safety and quality aspects of whole and skimmed milk powders. Acta Scientiarum Polonorum Technologia Alimentaria, v. 20, n.2, p. 165-177, 2021.

IRAGUHA, B.; HAMUDIKUWANDA, H.; MUSHONGA, B. Bovine mastitis prevalence and associated risk factors in dairy cows in Nyagatare District, Rwanda. Journal of The South African Veterinary Association, v.86, n.l, p. 1-6, 2015.

JAEGER, S. et al. Test characteristics of milk amyloid A ELISA, somatic cell count, and bacteriological culture for detection of intramammary pathogens that cause subclinical mastitis. Journal of Dairy Science, v.100, n.9, p.7419-7426, 2017.

KASIKCl, G. et al. Relations between electrical conductivity, somatic cell count, California mastitis test and some quality parameters in the diagnosis of subclinical mastitis in dairy cows. Turkish Journal of Veterinary and Animal Sciences, v.36, n.l, p. 49-55, 2012.

KLINE, K. E.; FLORES, S.; JOYCE, F. Factors affecting Somatic Cell Count in milk of dairy cows in Costa Rica. International Journal of Veterinary Science and Research, v.4, n.l, p. 001-008, 2018.

KRIECER, M. et al. Prevalence of production disease related indicators in organic dairy herds in four European countries. Livestock Science, v.198, p. 104-108, 2017.

LANGER, A. et al. Comparative efficacy of different mastitis markers for diagnosis of sub-clinical mastitis in cows. International Journal of Applied Sciences and Biotechnology, v.2, n.2, p.121-125, 2014.

LINZELL, J.; PEAKER, I. Mechanism of milk secretion. Physiological reviews.51, 1971.

LITWIŃCZUK, Z.; KRÓL, J.; BRODZIAK, A. Factors determining the susceptibility of cows to mastitis and losses incurred by producers due to the disease-a review. Annals of Animal Science, v.15, n.4, p. 819-831, 2015. 
MADUT, N. A.; GADIR, A. E. A.; ELJALII, I. M. Host determinants of bovine mastitis in semi-intensive production system of Khartoum state, Sudan. Journal of Cell and Animal Biology, v. 3, n.5, p. 071077, 2009.

MEKONNEN, S. A. et al. Prevalence of subclinical mastitis and associated risk factors at cow and herd level in dairy farms in North-West Ethiopia. Preventive Veterinary Medicine, v.145, p. 23-31, 2017.

MENDOZA, J. A.; VERA, Y. A.; PEÑA, L. C. Prevalence of subclinical mastitis, associated microorganisms and identified risk factors in dairy herds in the province of pamplona, norte de santander. Revista de la Facultad de Medicina Veterinaria y de Zootecnia, v.64, n.2, p.1l-24, 2017.

MIR, A. Q.; BANSAL, B. K.; GUPTA, D. K. Subclinical mastitis in machine milked dairy farms in Punjab: prevalence, distribution of bacteria and current antibiogram. Veterinary World, v. 7, n.5, 2014.

MPATSWENUMUGABO, J. P. et al. Prevalence of subclinical mastitis and distribution of pathogens in dairy farms of Rubavu and Nyabihu districts, Rwanda. Journal of Veterinary Medicine, 2017.

MUREITHI, D. K.; NJUGUNA, M. N. Prevalence of subclinical mastitis and associated risk factors in dairy farms in urban and peri-urban areas of Thika Sub County, Kenya, Livestock Research for Rural Development.v.28, n.2, p.l-10, 2016.

NESMA H.Y. et al. Influence of some hygienic measures on the prevalence of subclinical mastitis in a dairy farm. International Journal of Dairy Science, v.15, n.l, p. 38-47, 2020.

NORBERG, E. et al. Electrical conductivity of milk: ability to predict mastitis status. Journal of Dairy Science, v.87, n.4, p.1099-1107, 2004.

OLIVER, S. P. et al. Prevalence, risk factors, and strategies for controlling mastitis in heifers during the periparturient period. The International Journal of Applied Research in Veterinary Medicine, v.3, n.2, p.150-162, 2005.

ÖSTENSSON, K. et al. Prevalence of subclinical mastitis and isolated udder pathogens in dairy cows in Southern Vietnam. Tropical Animal Health and Production, v.45, n.4, p. 979-986, 2013.

PANCHAL, I.; SAWHNEY, I.K.; DANG, A.K. Relation between electrical conductivity, dielectric constant, somatic cell count and some other milk quality parameters in diagnosis of subclinical mastitis in Murrah buffaloes. Indian Journal of Dairy Science, v.69, n. 3, 2016.

PATEL, Y. G.; TRIVEDI, M. M. Effect of stage of lactation and parity on occurrence of subclinical mastitis. International Journal of Science, Environment and Technology, v.7, n.1, p. 250-253, 2018.

PRABHU, K. N. et al. Sub-clinical mastitis in buffaloes: prevalance, isolation and antimicrobial resistance of Staphylococcus aureus. Buffalo Bulletin, 34(2), 215-222, 2015.

QAYYUM, A. et al. Prevalence and Association of Possible Risk Factors with Sub-Clinical Mastitis in Cholistani Cattle. Pakistan Journal of Zoology, v. 48, n.2, 2016.

QUADERI, M. A. et al. Prevalence of sub-clinical mastitis in dairy farms. Bangladesh Veterinarian, v.30, n.2, p. 70-77, 2013.
RADOSTITS, O. M. et al. A textbook of the diseases of cattle, sheep, goats, pigs and horses. Veterinary Medicine 10th edition Bailliere, Tindall, London, UK, p. 1576-1580, 2007.

RAHMAN, M. M. et al. Prevalence of subclinical mastitis in dairy cows reared in Sylhet district of Bangladesh. International Journal of Bio Research, v.l, p. 23-28, 2010.

RAHMAN, M. A. et al. Prevalence and risk factors of mastitis in dairy cows. Bangladesh Veterinarian, v.26, n.2, p. 54-60, 2009.

SAMAD, M. A. Mastitis and gangrenous mastitis. Animal Husbandry and Veterinary Science, v.1l, p. 1492, 2008.

SARBA, E. J.; TOLA, G. K. Cross-sectional study on bovine mastitis and its associated risk factors in Ambo district of West Shewa zone, Oromia, Ethiopia. Veterinary world, v.10, n.4, p.398, 2017.

SCHALM, O. W.; CARROL, E. J.; JAIN, N. C. Bovine Mastitis. Lea and Febiger, Philadelphia, p. 20-158, 1971.

SEYOUM, B. et al. Prevalence, risk factors and antimicrobial susceptibility test of Staphylococcus aureus in Bovine cross breed mastitic milk in and around Asella town, Oromia regional state, southern Ethiopia. Acta Tropica, v.177, p. 32-36, 2018.

SHARMA, N.; SINGH, N. K.; BHADWAL, M. S. Relationship of somatic cell count and mastitis: An overview. Asian-Australasian Journal of Animal Sciences, v. 24, n.3, p. 429-438, 2011.

SHATHELE, M. S. Weather effect on bacterial mastitis in dairy cows. International Journal of Dairy Science, v.4, n. 2, p. 57-66, 2009.

SHAWKY, N. M. et al. A Biosecurity measures application with proper treatment to overcome the risk factors that limit effective control of subclinical mastitis in dairy buffalo farms- A field study. Nature and Science, v.11, n.7, p. 140-151, 2013.

SHELKE, V.B. et al. Prevalence of subclinical mastitis in dairy cows in and around Parbhani. The Pharma Innovation Journal. v. 8, n. 10, p. 78-81, 2019.

Singh, K. V. et al. Assessment of alteration in metabolic profile and milk composition of buffaloes with subclinical mastitis. Buffalo Bulletin, v.36, n.2, p. 349-356, 2017.

SUDHAN, N. A.; SHARMA, N. Mastitis-an important production disease of dairy animals. Gurgoan: Sarva Manav Vikash Samiti, p.72-88, 2010.

SULEIMAN, T. S.; KARIMURIBO, E. D.; MDEGELA, R. H. Prevalence of bovine subclinical mastitis and antibiotic susceptibility patterns of major mastitis pathogens isolated in Unguja island of Zanzibar, Tanzania. Tropical Animal Health and Production, v.50, n.2, p. 259-266, 2018.

SURIYASATHAPORN, W. Epidemiology of subclinical mastitis and their antibacterial susceptibility in smallholder dairy farms, Chiang Mai provinces, Thailand. Journal of Animal and Veterinary Advances, v.10, n.3, p. 316-321, 2011.

SYRIDION, D. et al. Effect of production systems on milk quality parameters in Holstein Friesian crossbred cows. Indian Journal of Dairy Science, v.66, n.5, p.424-431, 2013.

TANČIN, V. Somatic cell counts in milk of dairy cows under practical conditions. SlovakJournal of Animal Science, v.46, n.l, p.31-34, 2013. 
TIWARI, J. G. et al. Trends in therapeutic and prevention strategies for management of bovine mastitis: an overview. Journal of Vaccines and Vaccination, v.4, n.2, 2013.

TRAJCHEV, M. et al. Mastitis pathogens and their antimicrobial susceptibility in early lactating dairy cows. Poljoprivreda i Sumarstvo, v.63, n.l, P. 4l, 2017.

Vlkova, H. et al. Epidemiology of intramammary infections with Staphylococcus aureus and mastitis streptococci in a dairy cattle herd with a history of recurrent clinical mastitis. Polish Journal of Veterinary Sciences, v. 20, n.l, P. 133-139, 2017.

WANI, S. A.; BHAT, M. A. An epidemiological study on bovine mastitis in Kashmir valley. Indian Veterinary Journal, v.80, n.9, P. 841-844, 2003.

YOSHIDA, T. Relationships between milk yield, milk composition and electrical conductivity in dairy cattle. In proceedings-new zealand society of animal production, v. 65, n. 143. New Zealand Society of Animal Production; 1999, 2005.

YOUSSIF, N. H. et al. Genes conferring antimicrobial resistance in cattle with subclinical mastitis. Bulgarian Journal of Veterinary Medicine, 1311-1477, 2019; DOI: 10.15547/bjvm.2019-0028.

YOUSSIF, N.H. et al. Impact of subclinical mastitis on milk quality in different seasons. International Journal of Veterinary Science, v. 9, n.2, p. 313-316, 2020. DOI: 10.37422/IJVS/20.020.

ZERYEHUN, T.; ABERA, G. Prevalence and bacterial isolates of mastitis in dairy farms in selected districts of Eastern Harrarghe Zone, Eastern Ethiopia. Journal of Veterinary Medicine, 2017.

ZUCALI, M. et al. Milk flow pattern, somatic cell count and teat apex score in primiparous dairy cows at the beginning of lactation. Italian Journal of Animal Science, v.8, n.l, p.103-1ll, 2009. 